\title{
Kneeling for Hollywood
}

\author{
Melani McAlister
}

If you watched the first season of Showtime's Homeland (2011), you remember this scene: Sergeant Nicholas Brody has returned home after being held for years as a POW by the terrorist Abu Nidal. We have reason to believe-because the CIA tell us so-that "an American POW has been turned." Perhaps it is Brody. At first, he just seems beaten and fearful; tortured and distant but, still, probably a good guy. Then Brody goes out to the hardware store, where he shops slowly, picking up item after item, and putting each one down again. He lingers, ominously, over the electronic switches. Is he shopping for bomb-making supplies? We don't see what he buys, but back home he hides a bag from the hardware store in the garage. Later, near dawn, he sneaks back into the garage. We see him cleaning, fiddling. Then he pulls out the bag, which contains a small carpet. He puts it on the floor, and-with the garage door cracked just enough to show us the sun in the east-he begins to pray, kneeling and bowing, chanting in Arabic. The moment is meant to be shocking-chilling. We now know Brody has been converted to Islam. It wasn't bomb parts that he bought, but still we are forced to wonder: has he been "turned"? Is he now on the side of the terrorists? If we follow the logic of the show, Muslim prayer is part of our brief against him.

Ominous prayer by Muslims has long been a staple of Hollywood, so much so that twenty years ago The Siege (1998) used viewers' presumed associations with Muslim prayers against them. As the movie opens, after we have seen a terrorist leader abducted from his car in the desert, the scene fades into a shot of a muezzin calling the faithful to prayer. His voice, beautifully intoning "Allahu Akbar," is the background to other shots: of people praying in a house, and then of a large group of men in a mosque. We see a close-up of the muezzin's face, and then the camera pulls out to show the city skyline. We are no longer in the Middle East after all, but in New York, and the film plays with what it expects to be our shock. Islam is already here, the film tells us. And terrorism is on its way. ${ }^{1}$

Prayers are a visual shorthand in television and film, a way of marking a specific religion and signaling viewers' response to it. Americans come to their cultural texts familiar with the "right" kind of prayer, educated in the codes of ordinary sainthood by the decades of Christian prayers that Hollywood has bountifully provided for fans, from Ozzie and Harriet at dinner to Bonanza, where the silent-but-good cowboys gathered around the table. Not surprisingly, then, Christians generally make a better showing than other believers. In war movies, in particular, the good guys pray sincerely and righteously, if sometimes inelegantly. Think of Mel Gibson's supposed-to-be-heartwarming prayer in the Vietnam-era saga We Were Soldiers (2002), where he and a young Chris Klein kneel at the altar in a chapel, with stained glass of Mary and the baby Jesus watching over them, and ask God to protect them in battle. In Glory (1989), Morgan Freeman offers the prayers for a group of black soldiers fighting for the Union in the Civil War. He sounds like a preacher, his cause is impeccable, and his humble prayer tells us that our heroes are honorable.

Thank you to Brooke Blower, Carl Conetta, Kip Kosek, and Gayle Wald for their comments on earlier versions of this essay.

${ }^{1}$ On The Siege, see Melani McAlister, Epic Encounters: Culture, Media, and U.S. Interests in the Middle East Since 1945, 2nd ed. (Berkeley, CA, 2005), 259-65.

(C) The Author(s) 2018. Published by Cambridge University Press 
People pray, and their prayers are signifiers. From children's bedsides to every awkward Thanksgiving scene where somebody prays-cruelly or humorously or sanctimoniously-characters invoke God, but reveal themselves. We learn from the style of prayer, the lighting, and the tone of voice whether this praying person is to be trusted, whether goodness or terror or simply silliness is their likely next step.

The politics of prayer in Hollywood is not, however, so simple as "Christian prayer is good, Muslim prayer is bad." Muslim prayers can and have been presented as beautiful and movingalthough this is still surprisingly rare. And Christian prayers can be dangerous signs of madness. (Other prayers, Jewish or Buddhist or otherwise, work across a similar range.)

My nominee for ur text of macabre Christian prayer is The Night of the Hunter (1955). Robert Mitchum plays a psychopathic, itinerant preacher with "love" tattooed on the fingers of his right hand and "hate" on the fingers of his left. When Mitchum's preacher is jailed for thirty days for stealing a car, he meets a man who is about to be executed for robbing a bank. The preacher hatches a plan to find the man's widow and children and his stolen stash of money, and then kill the family (as he has killed many others). Mitchum's character prays gratefully for this opportunity from behind bars, the knife he has smuggled into the prison extending from the top of his clasped hands-a weaponized prayer, a self-deluded supplication, and a chilling moment of disclosure (Figure 1).

In Hollywood, dangerous Christians are those who believe in personal revelation-a God who is a bit too much on their side. In There Will Be Blood (2007), Daniel Day-Lewis's rapacious oil man Daniel Plainview faces off against Paul Dano's creepy Eli Sunday, a selfpromoting Pentecostal preacher who builds a church next to Plainview's oil well. The movie depicts the two as equally greedy-one for oil and money, the other for power and devotionwith capitalism and Christianity as twinned systems of extraction draining those who work the oil field. Two parallel scenes embody the conflict between the two men. First, Eli manipulates Daniel into kneeling in front of the church congregation and praying for repentance (Figure 2). Daniel is coerced to confess and be "washed in the blood of Jesus," forced to speak louder and louder: "I am a sinner. I am sorry, Lord. I want the blood." The extended scene is excruciating, anything but sacred-a demand for a public display of piety no matter

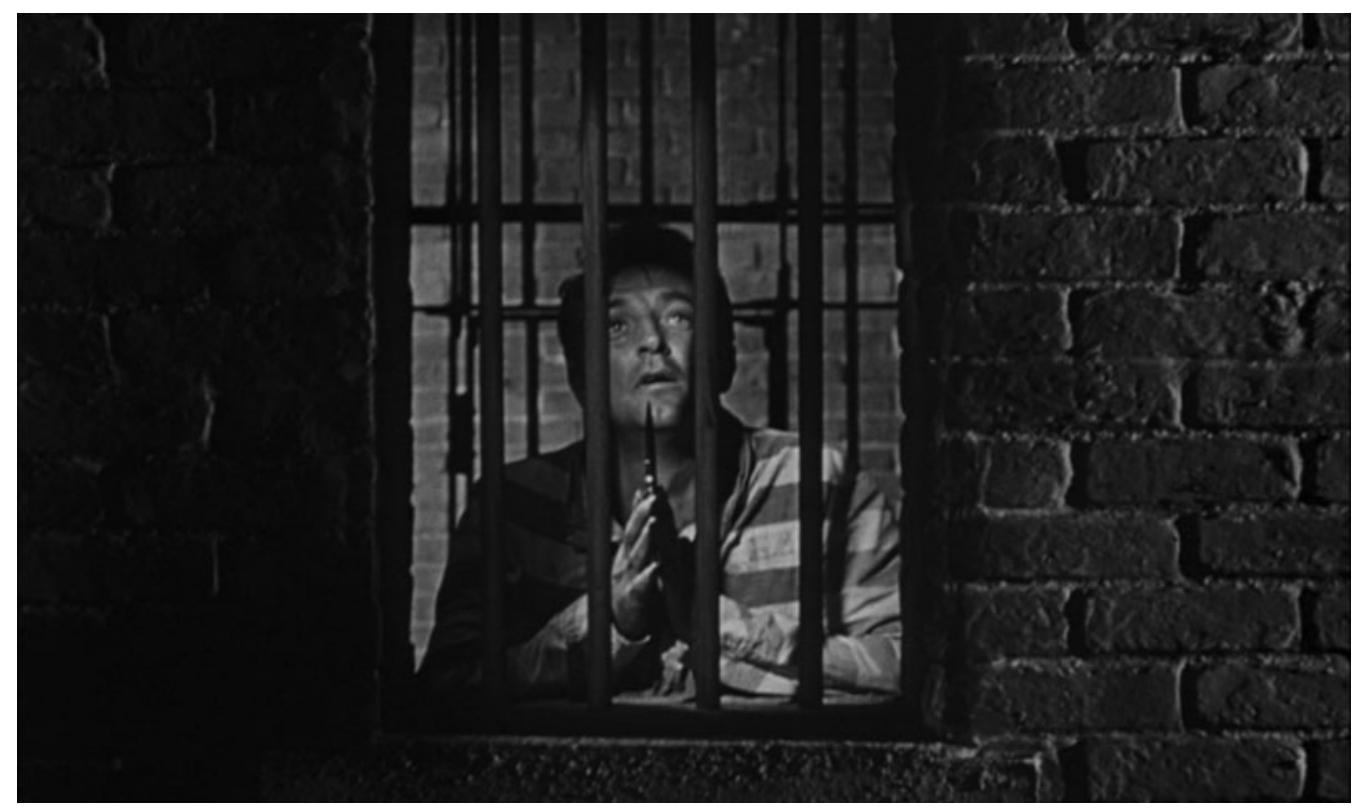

Figure 1. Robert Mitchum's preacher prays from his cell in The Night of the Hunter. 


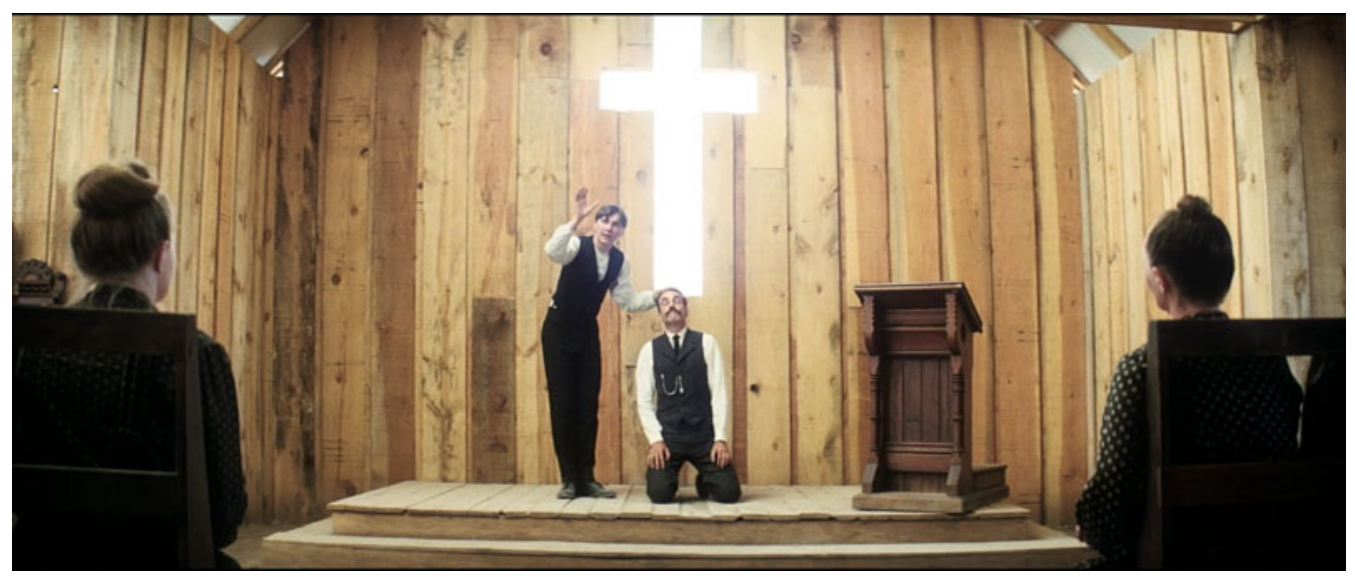

Figure 2. Eli teaches Daniel to pray in There Will be Blood.

what Daniel truly feels, a cynical performance on the part of both preacher and penitent. At the end of the film, Daniel extracts a reverse prayer out of Eli, forcing him to stand and to confess loudly that he is a "false prophet" and "God is a superstition." This, just before Daniel beats Eli to death with a bowling pin.

In Hollywood, prayer is often a synecdoche for religion in general. Since prayer is common to most religions, a prayer allows directors to short-hand "religion" by using something that is the-same-but-different in the religions that film and television parse. Showing people at prayer signifies religion without having to go into too many details about theology. No matter what religion, though, Hollywood has no time for prayers that are overly public, self-gratifying displays of piety-it always suspects such spectacles as hypocritical. Neither does our film and television approve of religion that is secret or overly zealous. No pious rants in front of the neighbors; no prayer rugs in the garage.

"Hollywood," of course, is not a single monster. It contains a (somewhat) diverse collection of directors, writers, actors, and others. They are not of one mind and disagree about many things-guns and women and race and the nature of baseball. And yet they do seem to agree on this: Religion can be a force for good, as long as it is rational, moderate, and tolerant.

In this, Hollywood is doing the work of secularism. The common description of secularism, as a political value and a state practice, is that it evinces a commitment to "separation of church and state." This, however, is a misrepresentation since, from the beginning, even a state that claims to divest itself from religion must decide what kind of thing religion is, in order to accord it special status. ${ }^{2}$ In the United States, for example, an employer cannot discriminate against a person with disabilities - unless that employer is a religious group. At the same time, people who want to smoke Peyote as part of a Native American ritual cannot claim an exemption from regular state laws against drug use. ${ }^{3}$ In each case, the courts have to decide whether a group is a religion, and if so just how special the rights of religions are. Yet our notions about "religious freedom" assume that there is a way for states to step back from religion

\footnotetext{
${ }^{2}$ Talal Asad, Formations of the Secular: Christianity, Islam, Modernity (Stanford, CA, 2003); Winnifred Fallers Sullivan, The Impossibility of Religious Freedom (Princeton, NJ, 2005); Matthew Scherer, Beyond Church and State: Democracy, Secularism, and Conversion (Cambridge, UK, 2013); Saba Mahmood, Religious Difference in a Secular Age: A Minority Report (Princeton, NJ, 2015); David Sehat, The Myth of American Religious Freedom (New York, 2011).

${ }^{3}$ Elliott Williams, "Resurrecting Free Exercise in Hosanna-Tabor Lutheran Church \& School v. EEOC 132 S. Ct. 694 (2012)," Harvard Journal of Law and Public Policy 36, no. 1 (Winter 2013): 391-402. Ira Lupu, David Masci, and Robert Tuttle, "A Delicate Balance: The Free Exercise Clause of the Supreme Court" (Washington, DC: Pew Forum on Religion and Public Life, Oct. 24, 2007), http://www.pewforum.org/2007/10/24/a-delicate-balance6/ (accessed Jun. 10, 2017).
} 
without necessarily first defining, and therefore limiting and regulating, the very thing they promise to ignore. ${ }^{4}$

As Talal Asad has argued, states (and scholars) often construct definitions of religion that they claim are universal, but which are based on experiences in the European Christian West, notably the idea that "religion" is a matter first and foremost of belief and individual conscience. ${ }^{5}$ Thus, in modern, secular states, religion is understood to be something private rather than public, as something personal and, as the Supreme Court put it, a matter of "honestly held belief." Prayer is useful for Hollywood because it can be used to signify belief-which, like passion, is notoriously hard to show in a visual medium. ${ }^{6}$

But this is not how all religions work. While most religions are more than just matters of individual conscience-they will have some practices that are communal and public, such as a Christian church service on Sunday-a number of religions are built fundamentally around the process of creating a community, of being in public together. A group might occupy spaces that they see as sacred, as with some Native American traditions; or perhaps their daily practices occupy a shared soundscape, as with the Muslim call to prayer, or a shared space, as with the Orthodox Jewish eruv. Such practices and communities are very hard for secular states to recognize as religion, which is why Peyote use or land claims by Native groups are often unprotected. ${ }^{7}$ In deciding what kinds of behaviors and beliefs to protect from state interference, then, the state actually organizes religion by locating certain practices and groups as authentic, while declaring others as not-really-a-religion. In doing so, it makes them all equally subject to state scrutiny. ${ }^{8}$

Hollywood is equally invested in declaring whether a given religious manifestation is legitimate or not. Sometimes-and increasingly since 9/11- Hollywood filmmakers want to show us that "Islam can be good" or "not all Muslims are terrorists." There are a number of strategies for doing so, including what Evelyn Alsultany describes as "simplified complex representations": images that announce themselves as liberal and complex, and thus appear to challenge former stereotypes, but which actually attempt to justify the problematic ways that Arab or Muslim characters are represented. ${ }^{9}$

We can see this logic at work in The Kingdom (2007). Jamie Foxx stars in the film as an FBI agent who goes to Saudi Arabia to investigate a terrorist attack on an American compound. The story is something of a typical action movie plot: they search for clues, they search for bad guys, they get into fire fights and car chases, and they succeed in the end. The film has a great deal to say about Saudi Arabia and Islam, and what it says is decidedly mixed. Saudi Arabia overall is shown as rife with corruption, and the streets of Riyadh are a source of constant danger: Violent terrorists are everywhere, seething with rage and armed with AK-47s. ${ }^{10}$

\footnotetext{
${ }^{4}$ Sullivan, Impossibility of Religious Freedom. For a U.S. foreign policy version of this argument, see Elizabeth Shakman Hurd, Beyond Religious Freedom: The New Global Politics of Religion (Princeton, NJ, 2015).

${ }^{5}$ On Asad, see R. Marie Griffith and Melani McAlister, "Introduction: Is the Public Square Still Naked?," in Religion and Politics in the Contemporary United States, ed. R. Marie Griffith and Melani McAlister (Baltimore, 2008), $1-25$.

${ }^{6}$ On the challenges of showing passion, see Linda Williams, Hard Core: Power, Pleasure, and the "Frenzy of the Visible" (Berkeley, CA, 1999); Jennifer Christine Nash, The Black Body in Ecstasy: Reading Race, Reading Pornography (Durham, NC, 2014).

${ }^{7}$ Tisa Wenger, We Have a Religion: The 1920s Pueblo Indian Dance Controversy and American Religious Freedom (Chapel Hill, NC, 2009).

${ }^{8} \mathrm{~A}$ fuller analysis of state regulation of religion would need to distinguish between several types of religious freedom and privilege as well as explore its quotidian bureaucratic forms, such as which groups count as a religion for the IRS or the local zoning board. See Tisa Wenger, Religious Freedom: The Contested History of an American Ideal (Chapel Hill, NC, 2017).

${ }^{9}$ Evelyn Alsultany, Arabs and Muslims in the Media: Race and Representation After 9/11 (New York, 2012).

${ }^{10}$ For a useful analysis of The Kingdom and the politics of Arabness and blackness, see Moustafa Bayoumi, "The Race Is On," Middle East Report, March 2010, http://www.merip.org/mero/interventions/race (accessed Jul. 14, 2017).
} 


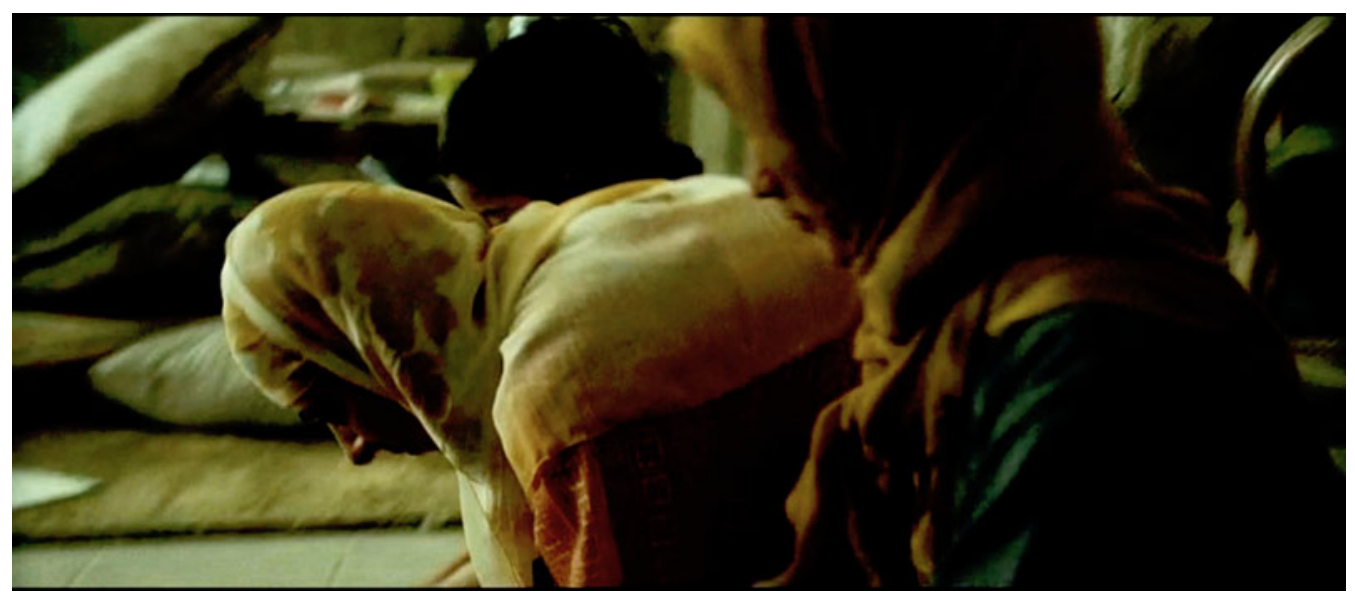

Figure 3. Al Ghazi's wife and daughter at prayer in The Kingdom.

But Foxx's character and his team work closely with one particular Saudi officer, Colonel Faris Al Ghazi, played by Ashraf Barhom, who is presented very positively-as a smart and kind and devout man, the "good Muslim." This is the complex representation that will serve as the alibi for the film's hostile depiction of Saudi Arabia in general. When The Kingdom wants us to understand the goodness of $\mathrm{Al} \mathrm{Ghazi,} \mathrm{as} \mathrm{well} \mathrm{as} \mathrm{the} \mathrm{film's} \mathrm{own} \mathrm{liberalism} \mathrm{about}$ Islam, it gives us $\mathrm{Al}$ Ghazi at prayer. In a long and almost silent set piece, the film shows him at home with his family. The scene is shot in a soft haze of yellow light, backed by beautiful, evocative music. At first Al Ghazi holds his son joyfully in his lap and does a drawing with one of his daughters; then he goes into a bedroom to pray with his bedridden father. Their prayer is paralleled by shots of the mother praying with her daughters in the next room (Figure 3). In many ways, the scene is genuinely important and lovely. The film is determined to present $\mathrm{Al}$ Ghazi as a committed believer in a religion worthy of respect.

But the terms of this respect are based on a prohibition: Islam is presented as "good" by being linked to family life. Within the terms of the film, it cannot be anything else. Al Ghazi's practice of Islam is never shown in a mosque. Although he is devout, he has nothing to say about any visions of public good or ideas about government; he does not care to ask the terrorists "even one question" about their motivations. Al Ghazi is presented as essentially apolitical, and his faith is a private, personal faith - the kind that narrows religion down to the line item of "belief" - a religion that does not claim to be a force in public life.

This is the kind of faith that secularism-and Hollywood-promotes and manages. Of course, even Hollywood does not always get its way. Just two years after The Kingdom was produced, a liberal, tolerant version of Islam was forced out of the former World Trade Center (WTC) site in New York, when anti-Muslim protests killed a plan to create a community center and mosque at the former Burlington Coat Factory, two blocks from the site of the planned WTC memorial. It did not matter that the Islamic Center would be something like a JCC or YMCA, a place for private prayer and public facilities like a gym and a pool. What mattered was that opponents could and did argue that there should be no "WTC Mosque," that Islam was too political, too violent, and would therefore desecrate the sanctified space where September 11 victims had died. ${ }^{11}$ And now once again, after the election of a president who campaigned on the promise of a "Muslim ban" on immigration, Muslim community advocates have rushed, as they had after $9 / 11$ and after every major crisis since, to show images of

\footnotetext{
${ }^{11}$ Winnifred Fallers Sullivan, "Religion, Land Rights," in Varieties of Religious Establishment, ed. Winnifred Fallers Sullivan and Lori G. Beaman (New York, 2016), 93-106.
} 
all-American Muslims-women in red-white-and-blue hijabs, men serving in homeless shelters, and families eating ice cream-to re-present Islam as the quiet and well-behaved counterpart to Protestant, Catholic, and Jew. Because Muslims and their allies know the norms of religious-political discourse in the United States. Until and unless they are allowed into the circle of "good religion," Muslims in America don't have a prayer.

Melani McAlister is associate professor of American Studies and International Affairs at George Washington University in Washington, DC. She is the author of Epic Encounters: Culture, Media, and U.S. Interests in the Middle East Since 1945 and The Kingdom of God Has No Borders: A Global History of American Evangelicalism, forthcoming in 2018. She is currently working on a book about the global response to the Nigeria-Biafra war. 